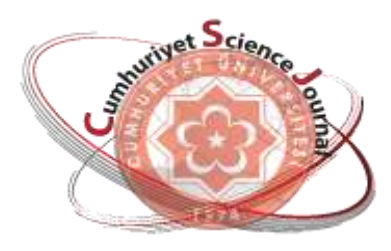

e-ISSN: $2587-246 X$

ISSN: $2587-2680$

\section{Cumanoryet Seienee Journal \\ $\cos$}

Cumhuriyet Sci. J., Vol.39-1(2018) 105-117

\title{
Investigation of NLO Properties of Pyridine Benzimidazole Derivatives: Ab-Initio Approach
}

\author{
Ayhan UNGORDU \\ Cumhuriyet University, Faculty of Science, Department of Chemistry, 58140 Sivas, TURKEY
}

Received: 27.09.2017; Accepted: 12.12.2017

http://dx.doi.org/10.17776/csj.405526

\begin{abstract}
Quantum chemical calculation analyses of pyridine benzimidazole and their derivatives are done at $\mathrm{HF} / 6-31+\mathrm{G}(\mathrm{d})$ level in gas phase. Geometric parameters, IR spectrum, ${ }^{1} \mathrm{H}-$ and ${ }^{13} \mathrm{C}-\mathrm{NMR}$ spectrum are calculated at $\mathrm{HF} / 6-31+\mathrm{G}(\mathrm{d})$ level in gas phase and examined in detail. In addition to these analyses, some quantum chemical descriptors which are related to non-linear optical (NLO) properties are calculated. Substituent effect on NLO properties are examined in detail and it is found that methyl group increases the NLO activity.
\end{abstract}

Keywords: Crossed square, Cornered crossed module, fibration

\section{Piridin Benzimidazol Türevlerinin NLO Özelliklerin İncelenmesi:}

\section{Ab-Initio Yaklaşımı}

Özet: Piridin benzimidazol ve türevlerinin kuantum kimyasal hesaplama analizleri, gaz fazında, HF/6-31+G(d) seviyesinde yapıldı. Bu bileşiklerin geometrik parametreleri, IR spektrumları, ${ }^{1} \mathrm{H}-\mathrm{ve}{ }^{13} \mathrm{C}-\mathrm{NMR}$ spektrumları detaylı şekilde incelendi. Bu analizlere ek olarak, lineer olmayan optik (NLO) özellikler ile ilgili kuantum kimyasal parametreler de hesaplandı. Ayrıca, NLO özellikler üzerine sübstitüent etkisi incelendi ve metil gruplarının NLO aktivitesini artırdı ğı bulundu.

Anahtar Kelimeler: Piridin benzimidazole, NLO özellikler, Moleküler modelleme, Ab-initio çalışması, Sübstitüent etkisi

\section{INTRODUCTION}

Common computational and experimental studies have been carried out on the structural, spectral and electronic properties of nonlinear optical (NLO) materials over the past two decades due to their potential applications in optoelectronic and a lot of optical devices [1-9].

The search determining new and good NLO materials has become an important research area so as to provide the requirements of developing technology. For this purpose, particularly, the $\pi$ conjugated molecular systems are satisfactory in terms of their NLO features due to they can treat as a donor and an acceptor [10-13].

It is reported that donor and acceptor molecules demonstrate high NLO features. Also, it is well known that proton or electron transfer compounds have a significant role in the field of magnetic, electrical conductivity and optical properties [1417].

Substituted pyridine benzimidazole compounds which have $\pi$-conjugated system are synthesized by Kathleen et al. (Scheme 1) [18]. Detailed 
quantum chemical study on structural, spectroscopic properties and NLO property of these compounds are not yet available. Therefore, quantum chemical calculation with ab-initio method has been used to examine different aspects of mentioned molecules.

Optimized molecule structures are obtained at $\mathrm{HF} / 6-31+\mathrm{G}(\mathrm{d})$ level in vacuo. Then IR, UV-VIS and NMR spectrum are calculated and examined in detail. Especially, four area (chloroform, DMSO, gas phase and water) are taken into account in calculation of UV-VIS spectrum. In these calculations, conductor polarized continuum model (C-PCM) is used to explain the solute - solvent interaction. Additionally, substituent effect over the NLO properties is investigated.<smiles>CCCn1c(-c2ccccn2)nc2ccccc21</smiles>

R: H

(I)

$\mathrm{R}: \mathrm{CH}_{3}$

(II)
$\mathrm{R}$ :<smiles>CCc1ccccc1</smiles>

(III)

$\mathrm{R}$ :<smiles>CCc1ccc(F)cc1</smiles>

$\mathrm{R}$ :<smiles>CCc1cc(F)cc(F)c1</smiles>

(V)<smiles>CCc1c(F)c(F)c(F)c(F)c1F</smiles>

\section{COMPUTATIONAL DETAILS}

HF calculations of molecule (I) - (VI) were carried out by using GaussView 5.0.8 [19], Gaussian 09 AML64-G09Revision-D.01 programs [20] and ChemBioDraw Ultra Version (15.1.0.144) [21]. All calculations were performed at $\mathrm{HF} / 6-31+\mathrm{G}(\mathrm{d})$ level in vacuum. The vibration frequency analyses indicate that optimized structures of relevant molecules are at stationary points corresponding to local minima without imaginary frequencies. Gauge-including-atomic-orbital (GIAO) method with $\mathrm{HF} / 6-31+\mathrm{G}(\mathrm{d})$ level was used to calculate NMR spectra for studied molecules. Some quantum chemical parameters which are total static dipole moment $(\mu)$, the average linear polarizability $(\alpha)$, the anisotropy of polarizability $(\Delta \alpha)$, the first hyperpolarizability $(\beta)$, optical softness $\left(\sigma_{0}\right)$, the biggest delocalization energy $\left(\mathrm{E}_{\text {Del. }}\right)$ and chemical potential $(\mathrm{CP})$ are calculated by using following equations [22]:

Scheme 1. The structures of studied compounds with atomic labelling. 


$$
\begin{aligned}
& \mu=\left(\mu_{x}^{2}+\mu_{y}^{2}+\mu_{z}^{2}\right)^{\frac{1}{2}} \\
& \alpha=\frac{1}{3}\left(\alpha_{x x}+\alpha_{y y}+\alpha_{z z}\right) \\
& \Delta \alpha=\frac{1}{\sqrt{2}}\left[\left(\alpha_{x x}-\alpha_{y y}\right)^{2}+\left(\alpha_{y y}-\alpha_{z z}\right)^{2}+\left(\alpha_{z z}-\alpha_{x x}\right)^{2}+6 \alpha_{x z}{ }^{2}+6 \alpha_{x y}{ }^{2}+6 \alpha_{y z}\right]^{\frac{1}{2}} \\
& \beta_{0}=\left[\left(\beta_{x x x}+\beta_{x y y}+\beta_{x z z}\right)^{2}+\left(\beta_{y y y}+\beta_{y z z}+\beta_{y x x}\right)^{2}+\left(\beta_{z z z}+\beta_{z x x}+\beta_{z y y}\right)^{2}\right]^{\frac{1}{2}} \\
& \sigma_{O}=\frac{1}{E_{L U M O}-E_{H O M O}} \\
& I=-E_{\text {HOMO }} \\
& A=-E_{L U M O} \\
& C P=-\left(\frac{2}{|I+A|}\right)
\end{aligned}
$$

Above equations were used in determination of NLO properties. Tetramethylsilane and urea were used as reference substances for NMR spectrum and in determination of NLO properties, respectively. Additionally, UV-VIS spectrum of each compound is calculated by time dependent method. Four areas are selected for UV-VIS spectrum. Dielectric constants of gas phase, chloroform, dimethylsulfoxide (DMSO) and water are $1,4.7113,46.826$ and 78.3553 , respectively.In solvent calculations, conductor polarized continuum model (C-PCM) is used to explain the solute - solvent interaction.

\section{RESULTS and DISCUSSION}

\subsection{Optimized Structures}

Entitled compounds are optimized at HF/6$31+\mathrm{G}(\mathrm{d})$ level in gas phase and optimized structures of mentioned molecules are given in Fig. 1. Some structural parameters of them are also given in Table 1. 


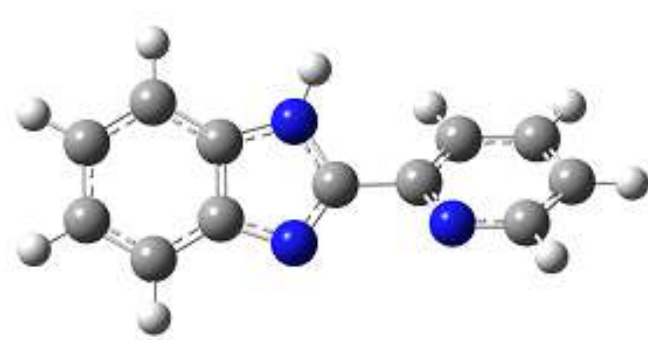

(I)

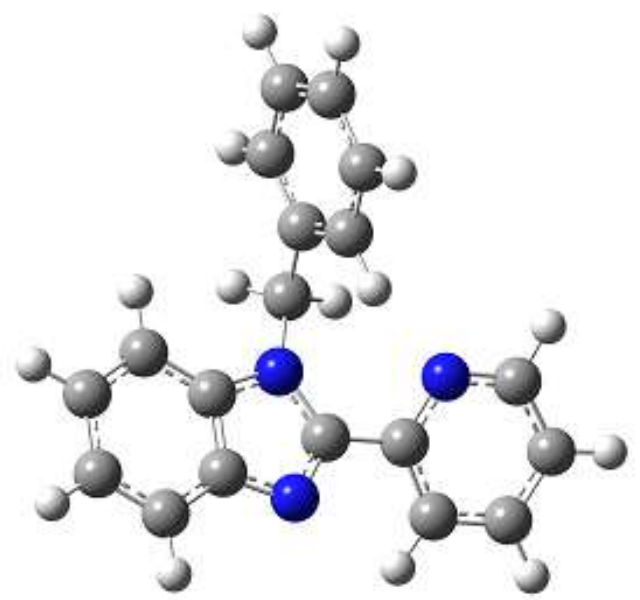

(III)

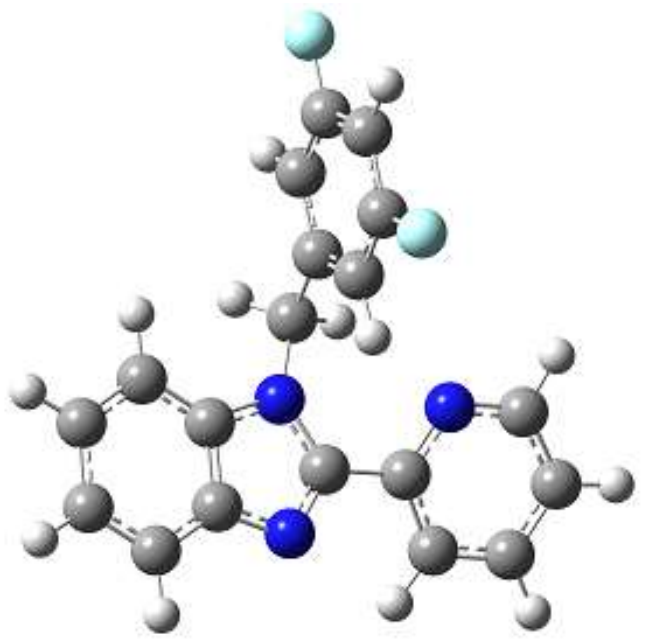

(V)

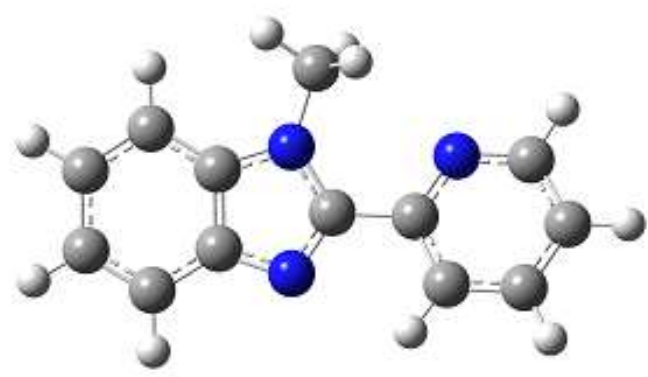

(II)

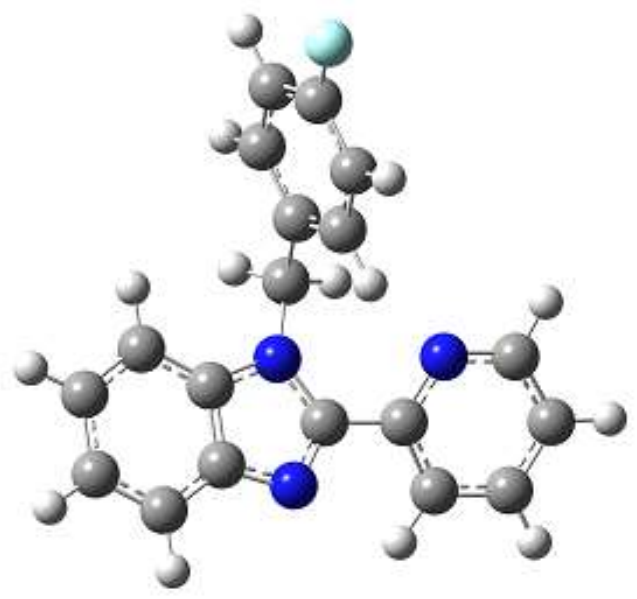

(IV)

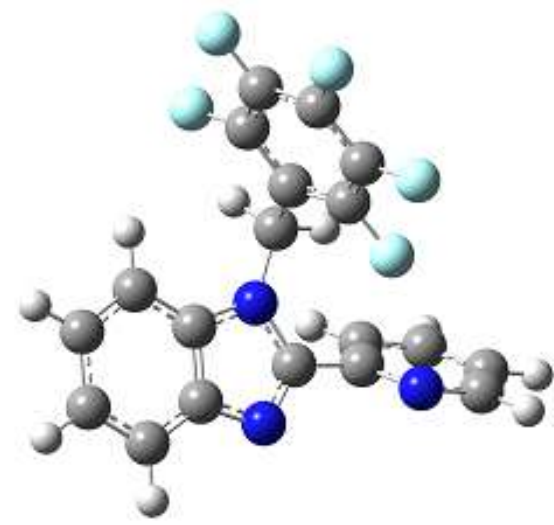

(VI)

Figure 1. Optimized structures of studied compounds at HF/6-31+G(d) level in vacuo. 
Table 1. Calculated some structural parameters of studied molecules

\begin{tabular}{|c|c|c|c|c|c|c|}
\hline & $\begin{array}{c}\text { Molecule } \\
\text { (I) }\end{array}$ & $\begin{array}{c}\text { Molecule } \\
\text { (II) }\end{array}$ & $\begin{array}{c}\text { Molecule } \\
\text { (III) }\end{array}$ & $\begin{array}{c}\text { Molecule } \\
\text { (IV) }\end{array}$ & $\begin{array}{c}\text { Molecule } \\
\text { (V) }\end{array}$ & $\begin{array}{c}\text { Molecule } \\
\text { (VI) }\end{array}$ \\
\hline \multicolumn{7}{|l|}{ Bond Lengths $(\AA)$} \\
\hline N1-C2 & 1.370 & 1.367 & 1.371 & 1.371 & 1.373 & 1.378 \\
\hline $\mathrm{N} 1-\mathrm{C} 9$ & 1.377 & 1.378 & 1.381 & 1.381 & 1.382 & 1.385 \\
\hline $\mathrm{N} 1-\mathrm{C} 10$ & - & 1.453 & 1.455 & 1.455 & 1.450 & 1.448 \\
\hline $\mathrm{C} 2-\mathrm{N} 3$ & 1.283 & 1.292 & 1.291 & 1.290 & 1.290 & 1.282 \\
\hline C2-C11 & 1.484 & 1.483 & 1.485 & 1.485 & 1.485 & 1.492 \\
\hline N3-C4 & 1.381 & 1.373 & 1.375 & 1.375 & 1.375 & 1.380 \\
\hline $\mathrm{C} 4-\mathrm{C} 5$ & 1.394 & 1.395 & 1.395 & 1.394 & 1.394 & 1.392 \\
\hline $\mathrm{C} 9-\mathrm{C} 8$ & 1.391 & 1.395 & 1.393 & 1.393 & 1.393 & 1.392 \\
\hline C11-N12 & 1.323 & 1.322 & 1.322 & 1.322 & 1.322 & 1.321 \\
\hline $\mathrm{C} 11-\mathrm{C} 16$ & 1.391 & 1.394 & 1.393 & 1.393 & 1.393 & 1.389 \\
\hline \multicolumn{7}{|l|}{ Bond Angles ( $\left.{ }^{\circ}\right)$} \\
\hline C10-N1-C2 & 125.62 & 129.67 & 130.22 & 130.05 & 130.37 & 128.27 \\
\hline C10-N1-C9 & 126.47 & 124.63 & 123.59 & 123.70 & 123.48 & 125.91 \\
\hline N1-C2-C11 & 120.96 & 124.98 & 125.47 & 125.37 & 125.39 & 123.24 \\
\hline N3-C2-C11 & 125.79 & 121.46 & 121.01 & 121.10 & 121.25 & 122.97 \\
\hline \multicolumn{7}{|l|}{ Dihedral Angle $\left(^{\circ}\right)$} \\
\hline N1-N2-C11-N12 & -39.08 & -18.92 & 23.85 & 24.99 & 20.57 & 118.48 \\
\hline N1-N2-C11-C16 & 143.03 & 160.44 & -155.18 & -153.93 & -158.32 & -65.67 \\
\hline N3-N2-C11-N12 & 140.66 & 162.44 & -157.93 & -156.85 & -161.11 & -63.94 \\
\hline N3-N2-C11-C16 & -37.21 & -18.18 & 23.03 & 24.22 & 19.99 & 111.90 \\
\hline N1-N3-C16-N12 & 132.93 & -18.64 & 23.54 & 24.66 & 20.41 & 105.41 \\
\hline
\end{tabular}

There are not significant differences in bond lengths and the bond angles. Substituents are changed a little them. However, there are important differences in dihedral angles. Substituents which change dihedral angles are quite altered the main skeleton of molecules. According to Table 1, it is found that molecule (I) and (VI) deviate from planarity.
IR spectra is substantial in determination of functional groups of molecules. IR spectrum of mentioned compounds are calculated at the same level of theory in gas phase and represented in Fig. 2. Calculated frequencies in Fig. 2 are harmonic and some stretching frequencies are given in Table 2. 


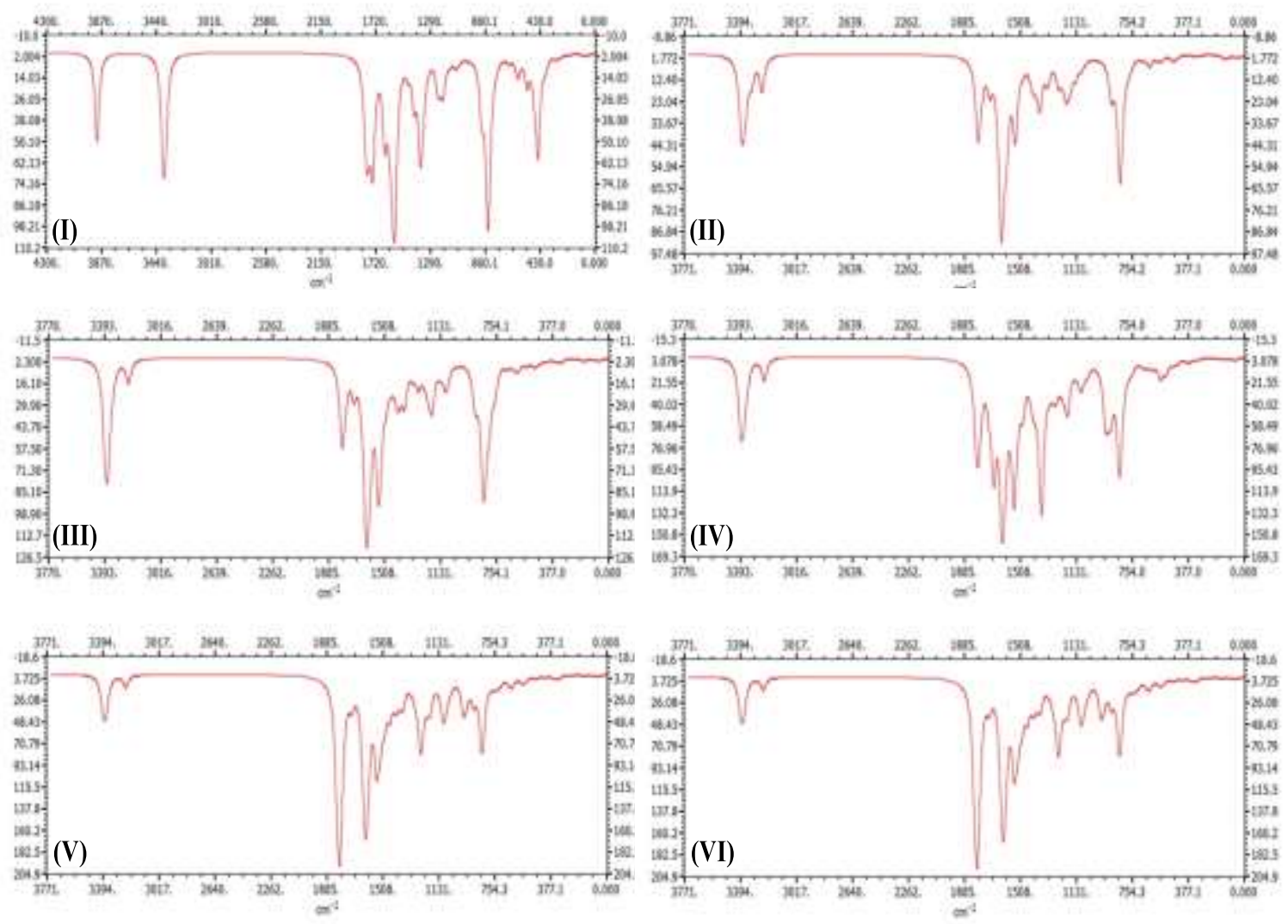

Figure 2. Calculated IR spectrum of studied compounds at same level of theory.

Table 2. Some calculated stretching frequencies $\left(\mathrm{cm}^{-1}\right)$ of related compounds at same level of theory.

\begin{tabular}{lllllll}
\hline Modes & Molecule (I) & $\begin{array}{c}\text { Molecule } \\
(\mathbf{I I})\end{array}$ & $\begin{array}{c}\text { Molecule } \\
(\text { III })\end{array}$ & $\begin{array}{c}\text { Molecule } \\
(\mathbf{I V})\end{array}$ & $\begin{array}{c}\text { Molecule } \\
(\mathbf{V})\end{array}$ & $\begin{array}{c}\text { Molecule } \\
(\mathbf{V I})\end{array}$ \\
\hline$v_{\mathrm{NH}}$ & 3910 & - & - & - & - & - \\
$v_{\mathrm{CH}}$ & 3374 & 3385 & 3373 & 3393 & 3386 & 3386 \\
$v_{\mathrm{CH} \text { (aliphatic) }}$ & - & 3252 & 3235 & 3235 & 3243 & 3278 \\
$v_{\mathrm{C}=\mathrm{C}}$ & 1797,1373 & 1796 & 1796 & - & 1795 & 1799 \\
$v_{\mathrm{C}=\mathrm{N}}$ & 1747,1571 & 1546 & 1555 & 1552 & 1554 & 1746 \\
$v_{\mathrm{CF}}$ & - & - & - & 1367 & 1255 & 1246 \\
\hline
\end{tabular}

Some functional groups which are (-NH), (-CF) and aromatic and aliphatic $(-\mathrm{CH})$ frequencies are given in Table 2. There are some deviations from expected frequencies due to the fact that the given frequencies are harmonic. For instance, the range of NH stretching frequencies is between $3300-$
$3500 \mathrm{~cm}^{-1}$. However, it is calculated as $3910 \mathrm{~cm}^{-1}$. Generally, harmonic frequencies can be corrected by scale factor. But, scale factor of $\mathrm{HF} / 6-31+\mathrm{G}(\mathrm{d})$ level is not available, yet. 


\subsection{UV-VIS Spectra}

UV-VIS spectrum of related compounds is Additionally, distribution graphs are plotted and calculated at the same level of theory in gas phase, represented in Fig. 3.

chloroform, DMSO and water. The main band of

related molecules in each area are given in Table 3.

Table 3. The main band of mentioned molecules in each area

\begin{tabular}{lcccccc}
\hline Area & $\begin{array}{c}\text { Molecule } \\
(\text { I })\end{array}$ & $\begin{array}{c}\text { Molecule } \\
(\text { II) }\end{array}$ & $\begin{array}{c}\text { Molecule } \\
(\text { III })\end{array}$ & $\begin{array}{c}\text { Molecule } \\
(\mathbf{I V})\end{array}$ & $\begin{array}{c}\text { Molecule } \\
(\mathbf{V})\end{array}$ & $\begin{array}{c}\text { Molecule } \\
(\mathbf{V I})\end{array}$ \\
\hline Gas Phase & 166.7 & 168.2 & 172.5 & 166.0 & 164.2 & 156.4 \\
Chloroform & 174.8 & 175.7 & 173.3 & 170.4 & 168.9 & 160.6 \\
DMSO & 174.6 & 175.4 & 170.8 & 169.4 & 168.6 & 160.0 \\
Water & 172.8 & 174.5 & 172.8 & 169.1 & 167.6 & 159.8 \\
\hline
\end{tabular}

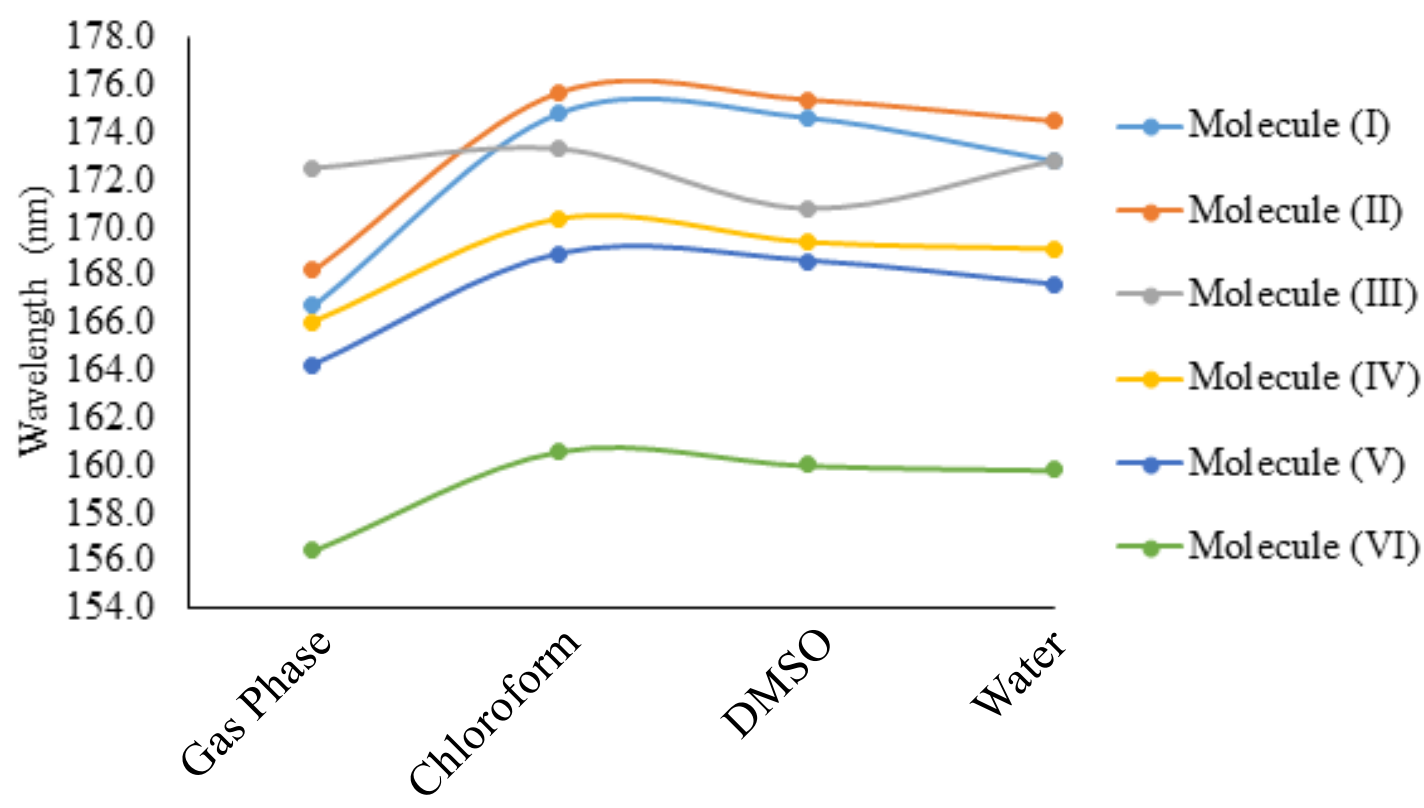

Figure 3. Distribution graph of main band of mentioned molecule for each area.

According to Fig. 3, the wavelength of the main band of molecule (I) increases in any solvent rather than gas phase expect molecule (III). In addition to these results, the wavelength mainly decreases with increasing of dielectric constant except gas phase. Electronic mobility between molecular orbitals is more in any solvent area than gas phase. Because the wavelength of main band in any solvent is higher than gas phase. These results imply that required energy is lower in solvent area than gas phase. This situation increases some electronic properties which are NLO properties and chemical reactivity. Therefore, these properties increase in solvent area than those of gas phase. 


\subsection{NMR Spectra}

Chemical shifts values of hydrogen and carbon atoms in studied molecule are calculated by using $\mathrm{HF} / 6-31+\mathrm{G}(\mathrm{d})$ level with GIAO method in gas phase. Additionally, these calculations, tetramethylsilane is calculated at same level of theory. Similarity of optimized structures are investigated by using chemical shift values of carbon and hydrogen atoms. Calculated ${ }^{13} \mathrm{C}-\mathrm{NMR}$ and ${ }^{1} \mathrm{H}-\mathrm{NMR}$ results are given in Table 4. Also, ${ }^{13} \mathrm{C}$-NMR and ${ }^{1} \mathrm{H}-\mathrm{NMR}$ spectrums are given in Fig. 4.

Table 4. Calculated NMR spectrum of related compounds at HF/6-31+G(d) level in gas phase.

\begin{tabular}{|c|c|c|c|c|c|c|}
\hline & $\begin{array}{l}\text { Molecule } \\
\text { (I) }\end{array}$ & $\begin{array}{c}\text { Molecule } \\
\text { (II) }\end{array}$ & $\begin{array}{l}\text { Molecule } \\
\text { (III) }\end{array}$ & $\begin{array}{c}\text { Molecule } \\
\text { (IV) }\end{array}$ & $\begin{array}{c}\text { Molecule } \\
\text { (V) }\end{array}$ & $\begin{array}{l}\text { Molecule } \\
\text { (VI) }\end{array}$ \\
\hline \multicolumn{7}{|c|}{${ }^{13} \mathrm{C}-\mathrm{NMR}$ results } \\
\hline$\overline{C 2}$ & 132.159 & 132.802 & 133.405 & 133.39 & 132.897 & 135.321 \\
\hline$C 4$ & 123.691 & 121.844 & 122.226 & 122.214 & 121.974 & 123.109 \\
\hline C5 & 105.206 & 104.015 & 103.592 & 103.76 & 103.98 & 104.958 \\
\hline C6 & 102.143 & 101.701 & 102.246 & 102.399 & 102.71 & 102.845 \\
\hline$C 7$ & 105.206 & 104.731 & 104.753 & 104.932 & 105.387 & 104.958 \\
\hline C8 & 89.852 & 89.896 & 91.966 & 91.64 & 90.929 & 89.658 \\
\hline$C 9$ & 113.938 & 117.162 & 117.061 & 116.888 & 116.716 & 113.667 \\
\hline $\mathrm{ClO}$ & - & 14.307 & 28.238 & 27.725 & 27.593 & 16.317 \\
\hline C11 & 134.307 & 134.667 & 134.583 & 134.487 & 133.931 & 134.514 \\
\hline C13 & 133.233 & 128.929 & 129.127 & 129.167 & 129.182 & 132.695 \\
\hline C14 & 101.436 & 101.273 & 101.517 & 101.678 & 101.847 & 101.563 \\
\hline C15 & 119.794 & 120.387 & 120.71 & 120.924 & 120.902 & 119.118 \\
\hline C16 & 100.123 & 104.522 & 105.031 & 105.105 & 104.896 & 102.605 \\
\hline \multicolumn{7}{|c|}{${ }^{1} \mathrm{H}-\mathrm{NMR}$ results } \\
\hline $\mathrm{N} 1 H$ & 25.275 & - & - & - & - & - \\
\hline $\mathrm{C} 5 \mathrm{H}$ & 24.397 & 24.538 & 24.557 & 24.545 & 24.491 & 24.509 \\
\hline $\mathrm{C} 6 \mathrm{H}$ & 25.254 & 25.286 & 25.309 & 25.297 & 25.233 & 25.237 \\
\hline $\mathrm{C} 7 \mathrm{H}$ & 25.176 & 25.164 & 25.35 & 25.324 & 25.251 & 25.208 \\
\hline $\mathrm{C} 8 \mathrm{H}$ & 25.187 & 25.234 & 25.438 & 25.453 & 25.473 & 25.237 \\
\hline $\mathrm{C} 13 \mathrm{H}$ & 23.484 & 23.716 & 23.834 & 23.809 & 23.921 & 23.426 \\
\hline $\mathrm{C} 14 H$ & 25.332 & 25.364 & 25.341 & 25.313 & 25.337 & 25.216 \\
\hline $\mathrm{C} 15 H$ & 24.558 & 24.502 & 24.459 & 24.439 & 24.45 & 24.52 \\
\hline $\mathrm{C} 16 \mathrm{H}$ & 25.185 & 23.753 & 23.772 & 23.806 & 23.705 & 25.321 \\
\hline
\end{tabular}


(I)
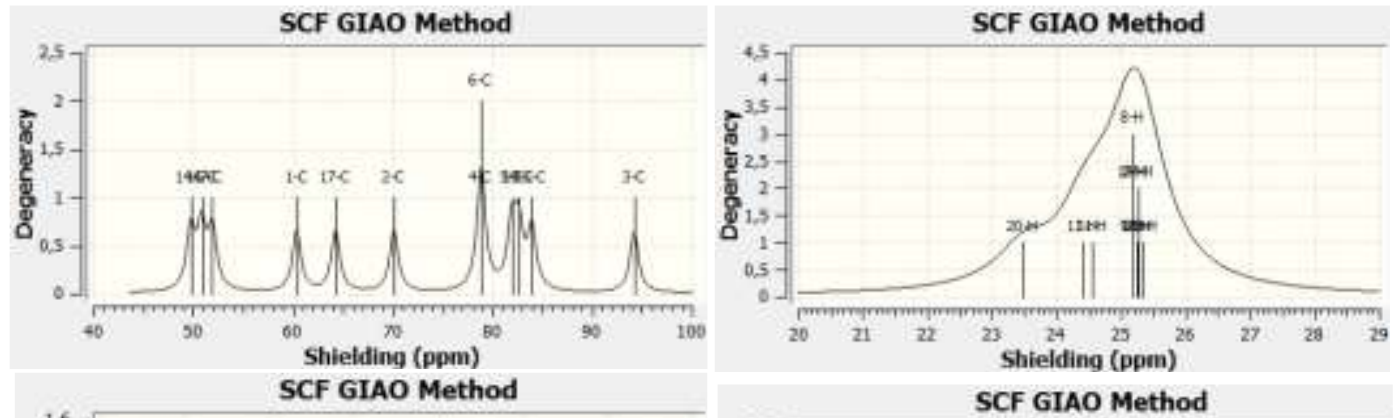

(II)
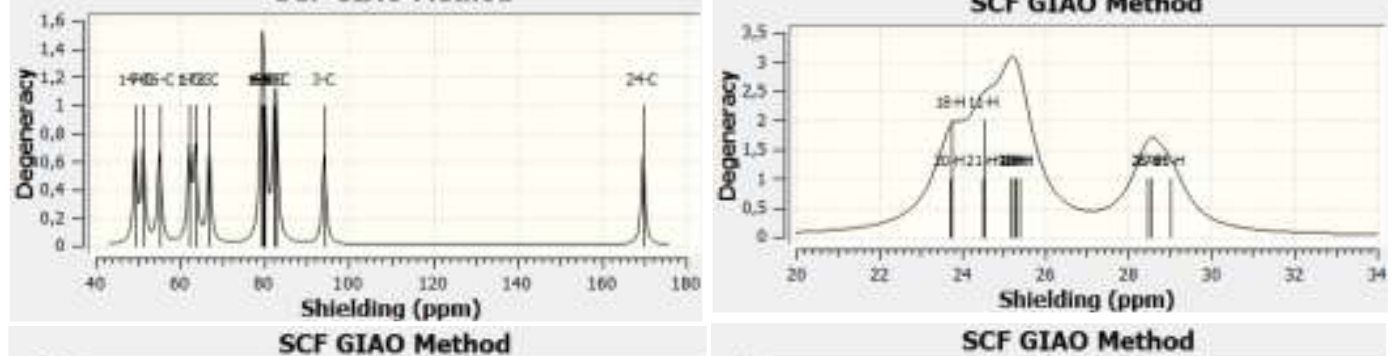

(III)
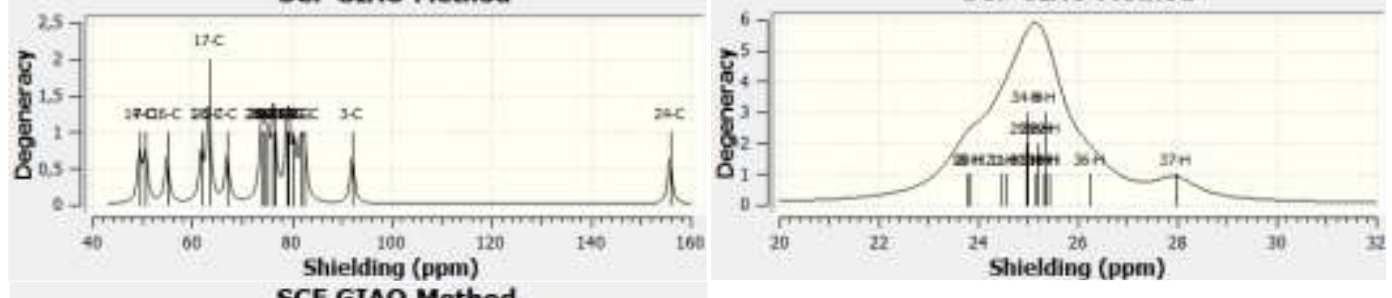

(IV)
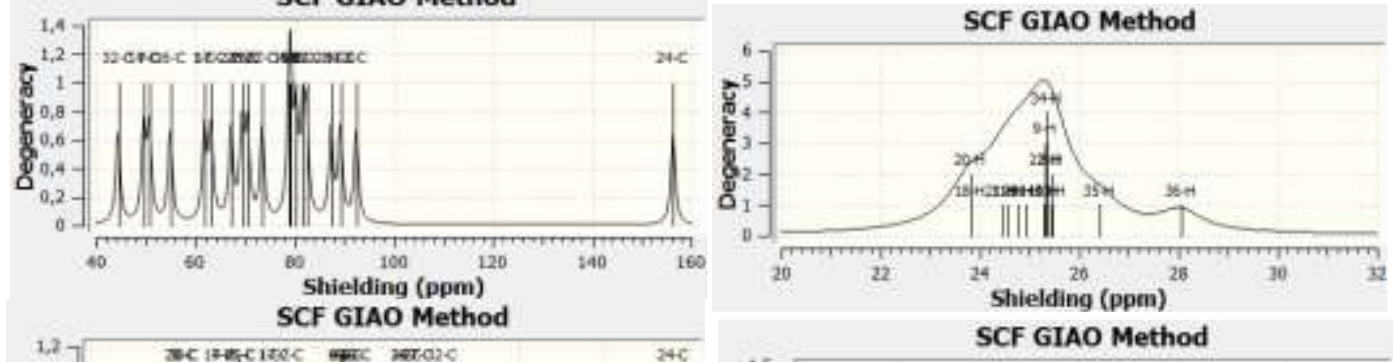

(V)
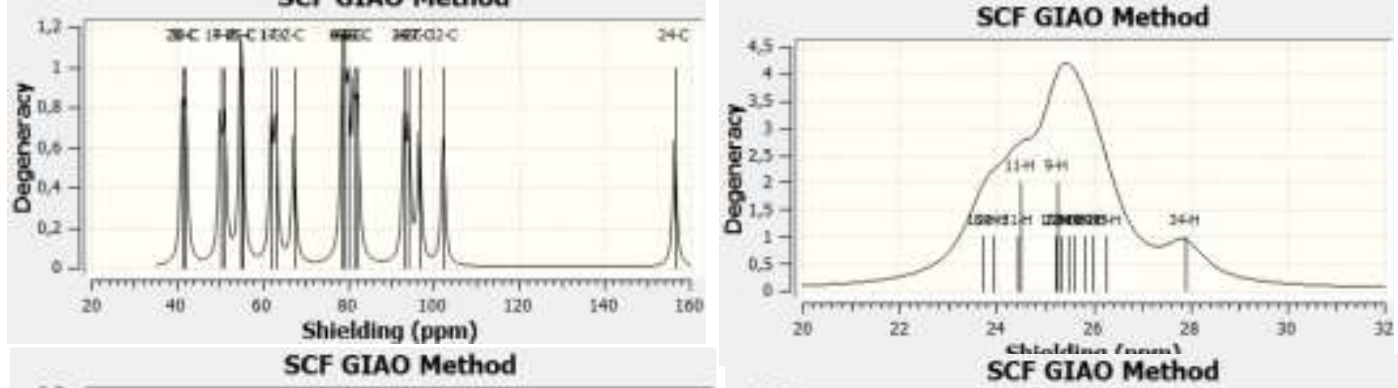

(VI)
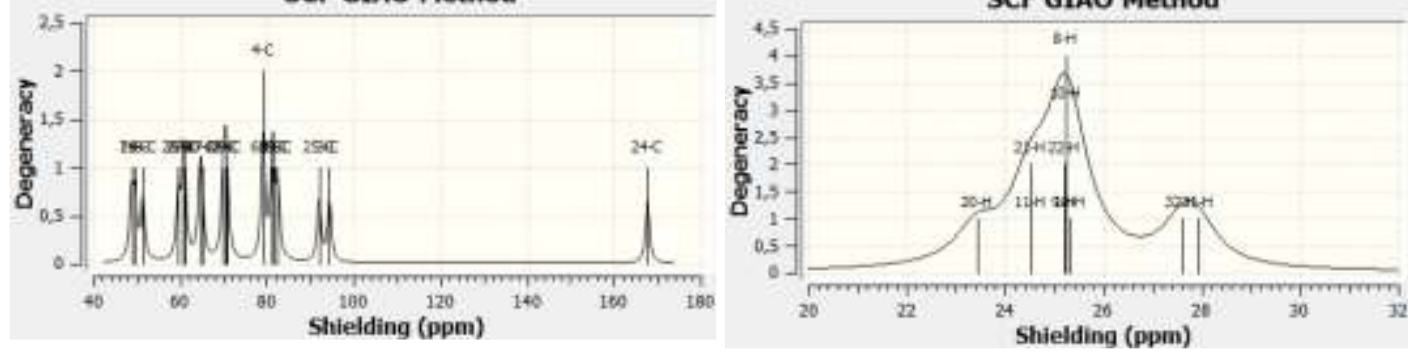

Figure 4. ${ }^{13} \mathrm{C}-\mathrm{NMR}$ and ${ }^{1} \mathrm{H}-\mathrm{NMR}$ spectrums of studied compounds at same level of theory.

Referring to Table 4, chemical shifts of aromatic carbon atoms are calculated in the range of 89-135 $\mathrm{ppm}$. These results are appropriate with theoretical expectation. There are aliphatic carbon atoms in molecules and their chemical shifts values are within range of 14-29 $\mathrm{ppm}$. These results are appropriate with theoretical expectations. As for 
the chemical shift values of hydrogen atoms, all results are quite compatible with each other.

\subsection{Non-linear optical (NLO) properties}

NLO is important feature in providing the key functions in technological areas. Thus, NLO is located in the foreground in current research. NLO properties can be affected by planarity of molecule, functional groups, $\pi$ electron delocalization and area. Especially planarity and $\pi$ electron delocalization are so important for NLO properties. Planarity and $\pi$ electron delocalization increase the NLO properties of molecule. Some quantum chemical parameters which are total static dipole moment $(\mu)$, the average linear polarizability $(\alpha)$, the anisotropy of the polarizability $(\Delta \alpha)$, first hyperpolarizability $(\beta)$ optical softness $\left(\sigma_{0}\right)$, the biggest delocalization energy $\left(\mathrm{E}_{\text {Del. }}\right)$ and chemical potential (CP) are calculated by Eq. (1) - (11). In terms of planarity, molecule (I) and (VI) is significantly deviated from planarity. Dihedral angles belong to these molecules are given in Table 1. Due to the fact that molecule (I) and (VI) are neglected in determination of NLO properties. HOMO energy and calculated quantum chemical parameters are given in Table 5.

Table 5. Calculated quantum chemical parameters for mentioned molecule at same level of theory in vacuo

\begin{tabular}{lllllllll}
\hline Molecule & $\mu^{1}$ & $\alpha^{2}$ & $\Delta \alpha^{2}$ & $\beta^{3}$ & $\sigma_{\mathrm{O}}{ }^{4}$ & $\mathrm{E}_{\text {Del. }}{ }^{5}$ & $\mathrm{CP}^{4}$ & E $_{\text {HOMO }}{ }^{6}$ \\
\hline (II) & 1.208 & 19.687 & 54.390 & $5.793 \times 10^{-27}$ & 9.632 & 160.19 & -0.114 & -0.291 \\
(III) & 1.185 & 26.505 & 54.142 & $4.513 \times 10^{-27}$ & 9.577 & 81.33 & -0.116 & -0.292 \\
$($ IV) & 1.405 & 26.403 & 55.062 & $5.596 \times 10^{-27}$ & 9.583 & 80.65 & -0.120 & -0.296 \\
(V) & 1.359 & 25.902 & 55.165 & $5.499 \times 10^{-27}$ & 9.636 & 78.96 & -0.121 & -0.298
\end{tabular}

${ }^{1}$ in Debye, ${ }^{2}$ in $\AA^{3},{ }^{3}$ in $\mathrm{cm}^{5} / \mathrm{esu},{ }^{4}$ in $\mathrm{eV}^{-1},{ }^{5}$ in $\mathrm{kcal} \mathrm{mol}^{-1},{ }^{6}$ in eV

NLO properties increase with increasing of all parameters. It is calculated that mentioned parameters of related molecules are higher than those of urea. Hence, NLO properties of studied molecules are better than urea. The ranking of NLO activity for each parameter is given as follow:

$$
\begin{aligned}
& \text { Molecule (IV) }>\text { Molecule (V) }>\text { Molecule (II) }>\text { Molecule (III) (in } \mu \text { ) } \\
& \text { Molecule (III) }>\text { Molecule (IV) }>\text { Molecule (V) }>\text { Molecule (II) (in } \alpha) \\
& \text { Molecule (V) }>\text { Molecule (III) }>\text { Molecule (IV) }>\text { Molecule (I1) (in } \Delta \alpha) \\
& \text { Molecule (II) }>\text { Molecule (IV) }>\text { Molecule (V) }>\text { Molecule (III) (in } \beta) \\
& \text { Molecule (III) } \left.>\text { Molecule (IV) }>\text { Molecule (II) }>\text { Molecule (V) (in } \sigma_{0}\right) \\
& \text { Molecule (II) } \left.>\text { Molecule (IV) }>\text { Molecule (V) }>\text { Molecule (III) (in } \mathrm{E}_{\text {Del., }} \mathrm{CP}, \mathrm{E}_{\mathrm{HOMO} O}\right)
\end{aligned}
$$

According to these rankings, molecule (II) is the best candidate for NLO properties. Additionally, MEP maps of related compounds are given in Fig. 5. 
(II)

$-4.963 \times 10^{-2}+4.963 \times 10^{-2}$

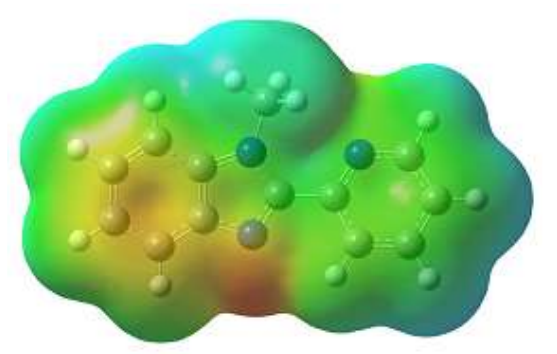

(III)

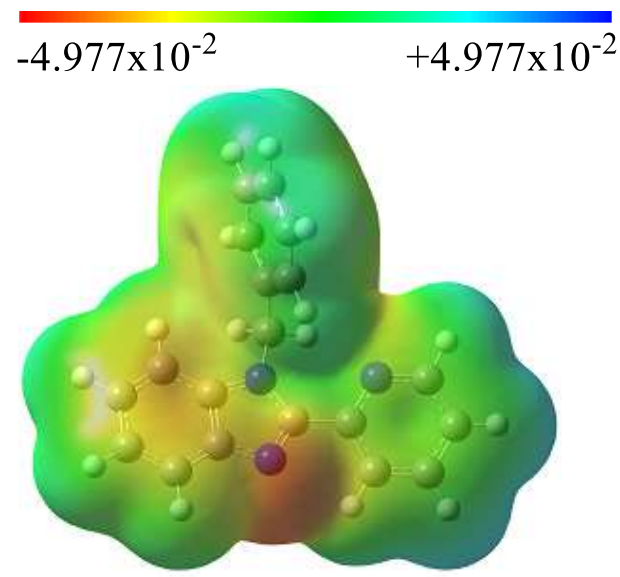

$-4.768 \times 10^{-2}$ $+4.768 \times 10^{-2}$

(IV)

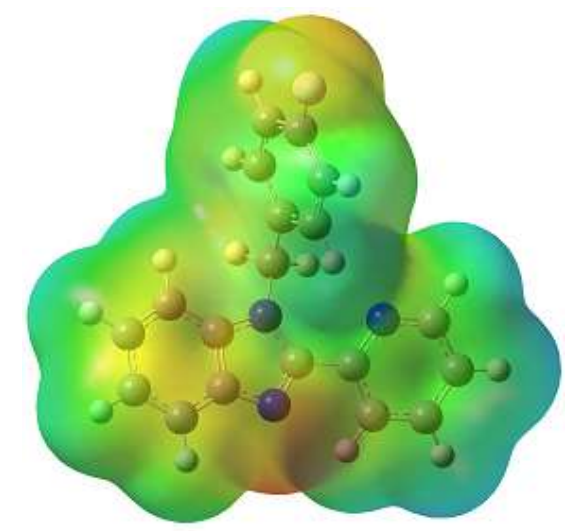

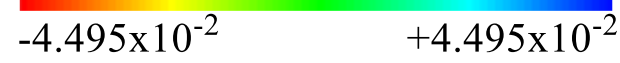

(V)

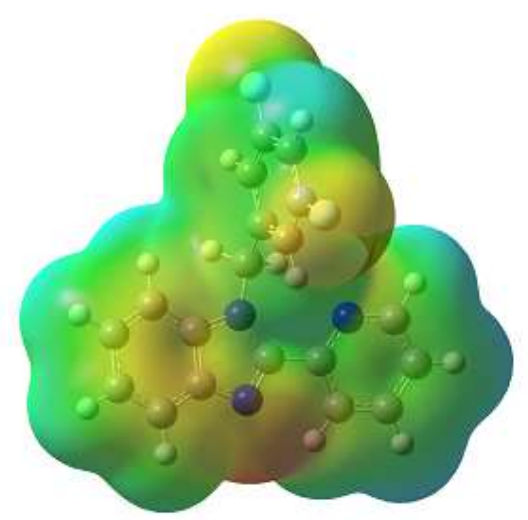

Figure 5. MEP maps of studied compounds except molecule (I) and (VI) at same level of theory.

According to Fig. 5, ESP charges are close to each other. However, molecular planarity of molecule (II) can easily see form this figure. Benzene and derivatives is distorted the whole molecular planarity. Methyl group is known as electron donating group and it increases the NLO properties of molecule. There are yellow regions on benzene ring due to the $\pi$ electrons. It is implied that this delocalization increases the NLO activity of molecule.

\section{CONCLUSIONS}

Computational investigations of pyridine benzimidazole compound derivatives are performed at $\mathrm{HF} / 6-31+\mathrm{G}(\mathrm{d})$ level. Optimized structures, IR, UV-VIS, ${ }^{1} \mathrm{H}-\mathrm{NMR}$ and ${ }^{13} \mathrm{C}-\mathrm{NMR}$ are calculated and investigated. It is found that there is not molecular planarity in molecule (I) and (VI). Similarities of mentioned molecules are supported by NMR spectrum. As for the UV-VIS spectrum, it is observed that electronic properties are more in solvent area. In addition to these results, NLO properties are investigated in detail and molecule (II) is the best candidate for NLO application.

\section{Acknowledgments}

The numerical calculations reported in this paper were fully/partially performed at TUBITAK ULAKBIM, High Performance and Grid Computing Center (TRUBA resources). 


\section{REFERENCES}

[1] Zyss J., Molecular Nonlinear Optics: Materials, Physics and Devices, Academic Press, Boston, 1993.

[2] McDonagh A.M., Humphrey M.G., Samoc M., Luther-Davies B., Organometallic complexes for nonlinear optics. 17.1 Synthesis, third-order optical nonlinearities, and two-photon absorption cross section of an alkynylruthenium dendrimer, Organometallics, 18 (1999) 5195-5197.

[3] Zhou X., Feng J.K., Ren A.M., One-and two-photon absorption properties of octupolar molecules with tetrahedral structure, Chemical physics letters, 403 (2005) 7-15.

[4] Ibersiene F., Hammoutene D., Boucekkine A., Katan C., Blanchard-Desce M., DFT study of NLO properties of boroxine based octupolar molecules, Journal of Molecular Structure: THEOCHEM, 866 (2008) 58-62

[5] Guidara S., Feki H., Abid Y., Structural, vibrational, NLO, MEP, NBO analysis and DFT calculation of bis 2, 5dimethylanilinium sulfate, Journal of Molecular Structure, 1080 (2015) 176-187.

[6] Sayin K., Karakaş D., Structural, spectral, NLO and MEP analysis of the $\left[\mathrm{MgO}_{2} \mathrm{Ti}_{2}\left(\mathrm{OPr}^{i}\right)_{6}\right],\left[\mathrm{MgO}_{2} \mathrm{Ti}_{2}\left(\mathrm{OPr}^{i}\right)_{2}(\mathrm{acac})_{4}\right]$ and $\left[\mathrm{MgO}_{2} \mathrm{Ti}_{2}\left(\mathrm{OPr}^{i}\right)_{2}(\mathrm{bzac})_{4}\right]$ by DFT method, Spectrochimica Acta Part A: Molecular and Biomolecular Spectroscopy, 144 (2015) 176-182.

[7] Keypour H., Shayesteh M., Rezaeivala M., Sayin K., Dinuclear $\mathrm{Cu}(\mathrm{II})$ complexes of compartmental Schiff base ligands formed from unsymmetrical tripodal amines of varying arm lengths: Crystal structure of $\left[\mathrm{Cu}_{2} \mathrm{~L}^{1}\right]\left(\mathrm{ClO}_{4}\right)_{2}$ and theoretical studies, Journal of Molecular Structure, 11112 (2016) 110-118.

[8] Sayin K., Kurtoglu N., Kose M., Karakas D., Kurtoglu M., Computational and experimental studies of 2-[(E)hydrazinylidenemethyl]-6-methoxy-4-[(E)phenyldiazenyl]phenol and its tautomers,
Journal of Molecular Structure, 1119 (2016) 413-422.

[9] Singh R.K., Singh A.K., DFT calculations on molecular structure, spectral analysis, multiple interactions, reactivity, NLO property and molecular docking study of flavanol-2, 4-dinitrophenylhydrazone, Journal of Molecular Structure, 129 (2017) 128-141.

[10] Resmi K.S., Haruna K., Mary Y.S., Panicker C.Y., Saleh T.A., Al-Saadi A.A., Van Alsenoy C., Conformational, NBO, NLO, HOMO-LUMO, NMR, electronic spectral study and molecular docking study of N,NDimethyl-3-(10H-phenothiazin-10-yl)-1propanamine," Journal of Molecular Structure, 1112 (2016) 268-279.

[11] Wazzan N.A., Al-Qurashi O.S., Faidallah H.M., DFT/and TD-DFT/PCM calculations of molecular structure, spectroscopic characterization, NLO and NBO analyses of 4-(4-chlorophenyl) and 4-[4(dimethylamino) phenyl]-2-oxo-1, 2, 5, 6tetrahydrobenzo $[\mathrm{h}]$ quinoline-3-carbonitrile dyes, Journal of Molecular Liquids, 223 (2016) 29-47.

[12] Halim S.A., Ibrahim M.A., Synthesis, DFT calculations, electronic structure, electronic absorption spectra, natural bond orbital (NBO) and nonlinear optical (NLO) analysis of the novel 5-methyl-8H-benzo [h] chromeno [2, 3-b][1, 6] naphthyridine-6 (5H), 8-dione (MBCND), Journal of Molecular Structure, 1130 (2017) 543-558.

[13] Moustafa H., Elshakre M.E., Elramly S., Electronic structure and nonlinear optical properties (NLO) of 2, 4-di-aryl-1, 5benzothiazepine derivatives using DFT approach, Journal of Molecular Structure, 1136 (2017) 25-36.

[14] Xue D., Zhang S., Effect of hydrogen bonds on optical nonlinearities of inorganic crystals, Chemical physics letters, 301 (1999) 449-452.

[15] Xue D., Zhang S., Chemical bond analysis of the correlation between crystal structure and nonlinear optical properties of complex 
crystals, Physica B: Condensed Matter, 262 (1999) 78-83.

[16] Xue D., Ratajczak H., Effect of hydrogen bonds on physical properties of ammonium dihydrogenphosphate crystals, Journal of Molecular Structure: THEOCHEM, 716 (2005) 207-210.

[17] Latajka Z., Gajewski G., Barnes A.J., Xue D., Ratajczak H., Hyperpolarizabilities of some model hydrogen-bonded complexes: PM3 and ab initio studies, Journal of Molecular Structure, 928 (2009) 121-124.

[18] Prosser K.E., Chang S.W., Saraci F., Le P.H., Walsby C.J., Anticancer copper pyridine benzimidazole complexes: ROS generation, biomolecule interactions, and cytotoxicity, Journal of inorganic biochemistry, 167 (2017) 89-99.

[19] GaussView 5.0.8, Gaussian Inc., Wallingford, CT, USA, 2009.

[20] Gaussian 09, rev. D.01, Gaussian Inc., Wallingford, CT, USA, 2010.

[21] Perkin Elmer, 2016. ChemBioDraw Ultra Version (15.1.0.144), CambridgeSoft Waltham, MA, USA.

[22] Sayin K., Karakas D., Karakus N., Alagöz Sayin T., Zaim Z., Erkan Kariper S., Spectroscopic investigation, FMOs and NLO analyses of $\mathrm{Zn}(\mathrm{II})$ and $\mathrm{Ni}$ (II) phenanthroline complexes: A DFT approach Polyhedron, 90 (2015) 139-46. 